\title{
EGY KISTÉRSÉG SIKERÉNEK TITKA - AVAGY TETTEK ÉS TERVEK A NYUGATI-KAPU TÉRSÉGFEJLESZTÉSI TÁRSULÁS „HÁZATÁJÁN”
}

\section{(Main Factors of Success of the „Nyugati-Kapu” Region: Plans and Actions for Development) \\ SZÖRÉNYINÉ KUKORELLI IRÉN}

Magyarország gazdaságilag egyik legdinamikusabb területén, Györ-MosonSopron megyében, annak észak-nyugati részén, az osztrák és szlovák hármashatár menti területen helyezkedik el az a 12 település, amely számára az alábbiakban összefoglalt koncepció készült (1. ábra).

A Nyugati-Kapu Térségfejlesztési Társulás 1995-ben alakult meg. Az első lépésben nyolc település önkormányzata (Bezenye, Dunakiliti, Dunasziget, Feketeerdő, Hegyeshalom, Levél, Mosonszolnok, Rajka), illetve polgármestere kötelezte el magát az önkormányzati határokat átlépỏ gazdaságfejlesztés mellett. Alapító tagnak számít a Győr-Moson-Sopron Megyei Önkormányzat is, amely erkölcsi és anyagi támogatással egyaránt részt vesz a társulás munkájában. Alakuláskor a társulás területe $280,5 \mathrm{~km}^{2}$, lakónépessége 15.000 fỏ volt. A társulásnak jelenleg 12 tagja van, mert az alapító tagokhoz először Újrónafö, majd Mosonmagyaróvár, Jánossomorja, és végül Várbalog is csatlakozott. Mosonmagyaróvár csatlakozásával a térség városa, húzóereje is a társulás tagjává vált, de székhelye továbbra is Levél. Az új belépökkel egyưitt a társulás lélekszáma már meghaladja az 50 ezer főt, területe az $586 \mathrm{~km}^{2}-\mathrm{t}$. A "kapu" elnevezés ráillik a térségre, hiszen Levél, Mosonmagyaróvár és Hegyeshalom települések az M1-es autópálya (E60-as fớtvonal), Mosonmagyaróvár, Rajka, Jảnossomorja és Bezenye az E65-ös, E75-ös út mentén fekszik, igy a kistérségben három nemzetközi föútvonal találkozik.

A társulás 1996 évben a Megyei Területfejlesztési Tanács elsỏ pályázati kiírását kihasználva, megpályázta a térségfejlesztési koncepció készíttetését, s így a megyében elsök között készíttette el a térség társadalmi-, gazdasági analízisét és fejlesztési koncepcióját. A kutatás során kapott eredmények arra utaltak, hogy a térség nem egy átlagos vidéki térség, annak állapota, eredményei kedvezö jegyeket mutatnak a korábban górcsó alá vett térségekhez képest. Már a kutatómunka első fázisában megfogalmazódtak a kérdések, amelyek a hipotézis felállitásához vezettek.

- Miben, mely mutatók alapján ítélhetjük az átlagnál kedvezöbb helyzetủnek a térséget?

- Miben más ez a térség más határmenti régiókhoz képest?

- Melyek a térség erősségei?

- Melyek azok a tényezők, melyek gyorsították a térség fejlödését

- Mennyire homogén a térség, ami a fejlettséget illeti?

- Lehet-e azt mondani a térségröl, hogy "sikerrégió"? 


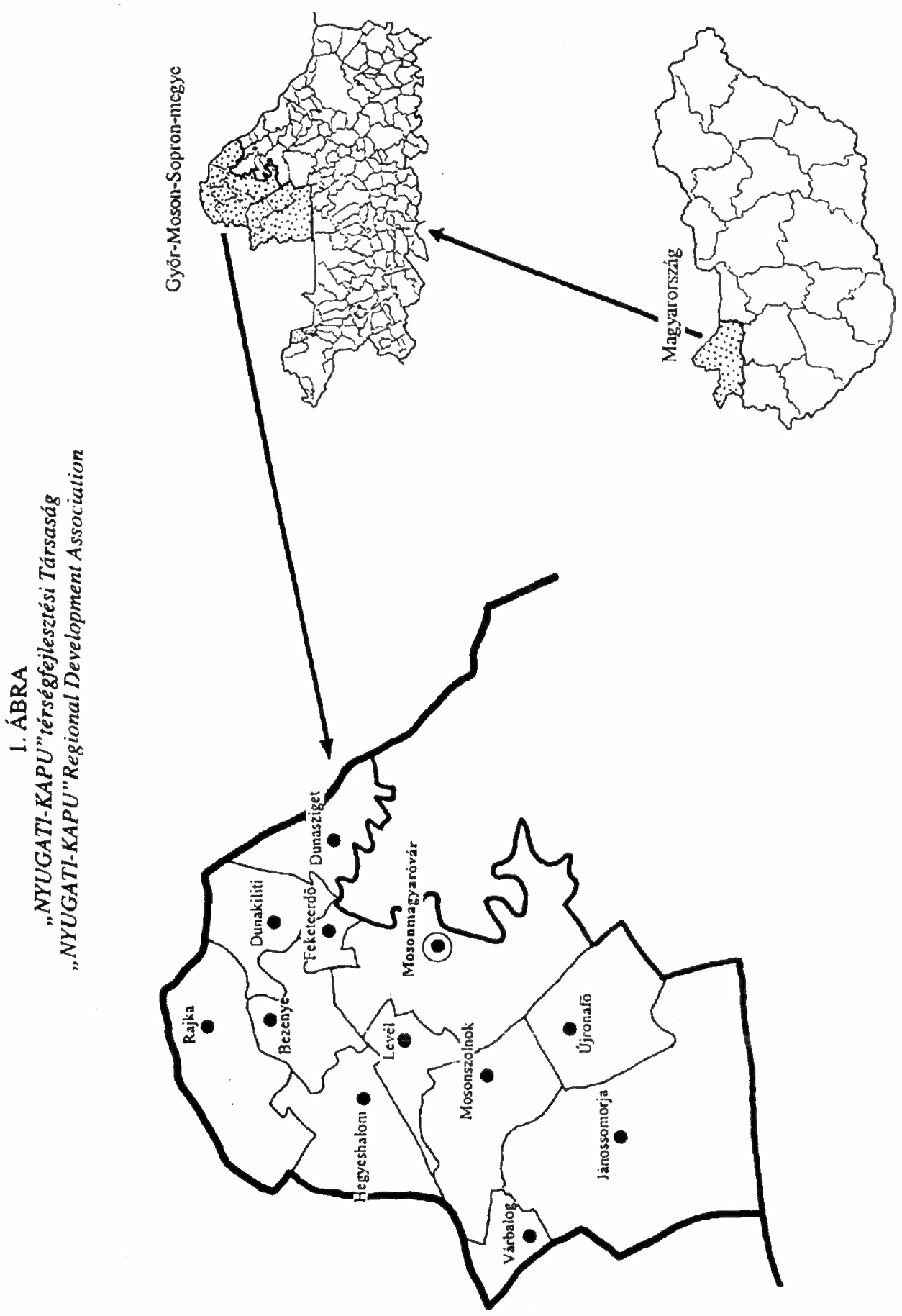


A feltett kérdésekre a rendelkezésre álló statisztikai adatok és a kutatás során megszerzett információk együttesen szolgáltak válasszal.

\section{A térséganalízis fóbb megállapitásai}

Az analízis során részletesen vizsgáltuk a gazdaság legfontosabb jellemvonásait, a humán tényező föbb aspektusait, az infrastruktúra jelenlegi kiépitettségi szintjét.

\section{A humán tényezö föbb aspektusai}

A térség egészére a kedvezö korösszetétel, a bevándorlás, az alacsony munkanélküliség jellemző, azaz dinamikus térség benyomását kelti. A térségben az elvándorlások száma a megyei értéknél jóval alacsonyabb, a vándorlási különbözet pozitív, azaz a térség népességbefogadó. 1980-tól a népességszám emelkedett (1980-ban 52.016 fö, 1995-ben 53.410 fö), az 1980 évihez képest 2,7\%-kal. Ez akkor következett be, amikor az ország népessége csökken, mivel a természetes szaporodás országos trendjei itt is érvényesülnek, a népesség növekedése elsösorban a bevándorlással magyarázható.

Köztudott, hogy a munkanélküliség Budapest után Győr-Moson-Sopron megyében a legalacsonyabb, de a megye rátájához képest - ahogyan azt a 2. ábra is mutatja ebben a térségben még kedvezöbb a helyzet, sőt a vizsgálatok is alátámasztották azt, hogy a térségben gyakorlatilag munkaerö-hiány lépett fel.

Jánossomorja, Mosonszolnok, Levél és Rajka települései, a második világháborút követő nagymértékủ kitelepítések ellenére német nemzetiségũ jellegét megtartotta. A németnyelv-tudás a határon túli munkavállalást is lehetövé tette, és legálisan vagy illegálisan, de már az 1980-as évek végén megindult a munkavállalók serege a határon túlra, közưlük legtöbben mezőgazdasági idénymunkát vállaltak, de jelentős számú volt a mesteremberek munkavállalása is.

A külföldi munkavállalásnak két hatása volt, részben megoldotta az 1990-es évek elején jelentkezö munkanélkưliségi problémát, vagyonosodási lehetöséget biztosított, illetve gazdasági kapcsolatok épitését indukálta. Így a gazdasági tapasztalatok és egy gazdasági társaság indításához szükséges tőke és kapcsolat egyszerre volt jelen. Röviden úgy fogalmazhatjuk, hogy magas a térség lakosságának adaptációs képessége.

Ugyanakkor érzékelni kell a lopakodó veszélyt is, hiszen ahol a megélhetés kedvezöbb feltételei vannak jelen, ott a deviáns, bünözö bevándorlók rétege is megjelenik. A térségben ez a jelenség összefuiggésbe hozható a tranzitforgalom folyamatos növekedésével. E kedvezötlen folyamat kiszürése csak úgy lehetséges, ha a negatív folyamat elé megyünk, $\mathrm{s}$ már annak kezelését kezdjük el.

A gazdaság föbb vonásai

A térség gazdasági szerkezetváltása a rendszerváltással egy időben kezdődött el. $\mathrm{Az}$ osztrák és német tulajdonú vegyes vállalatok ebben a térségben jelentek meg elöször, alig találunk itt olyan települést, ahol ne müködne külföldi érdekeltségũ gazdasági társaság. 


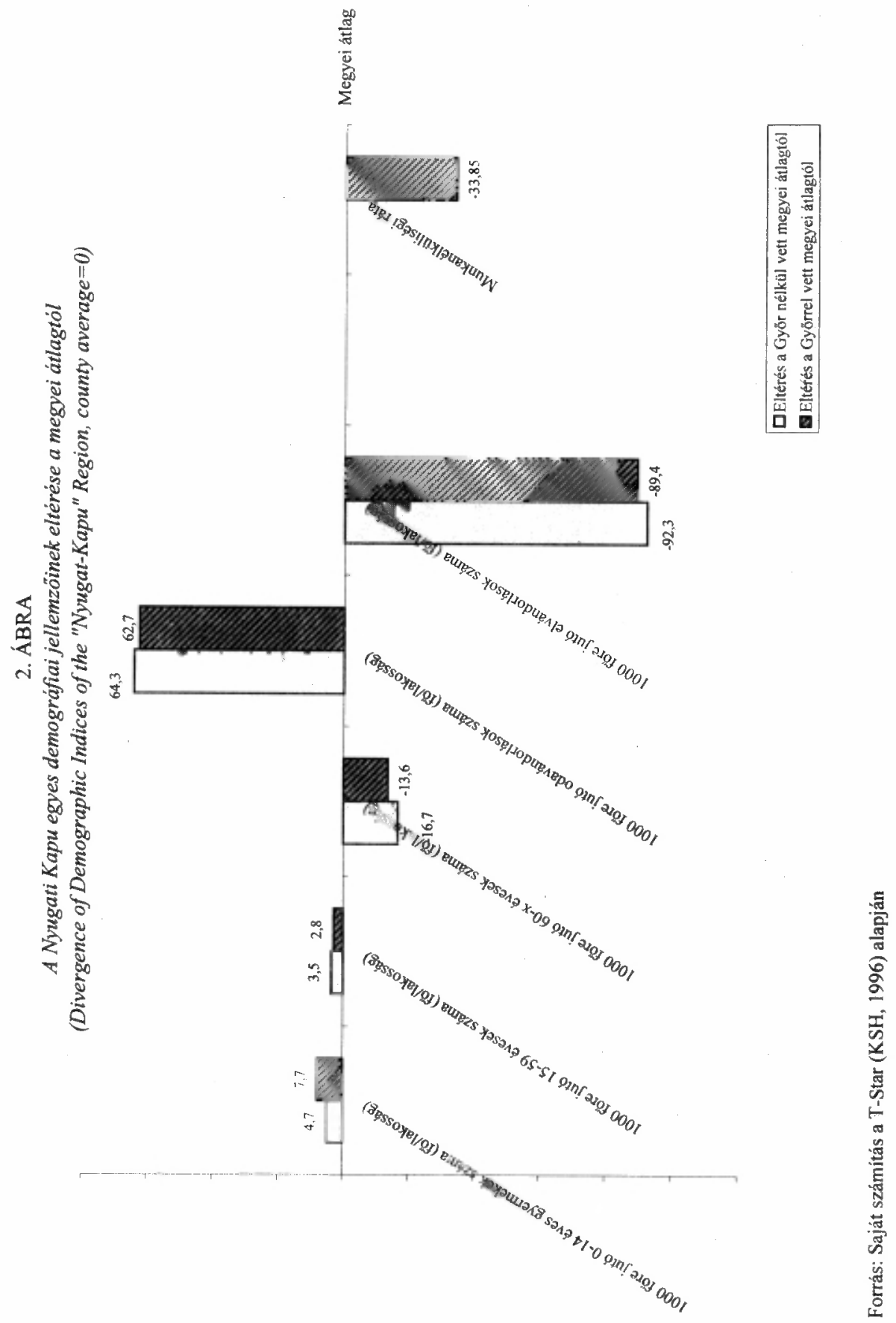


Mind a korlátolt felelősségü, mind a betéti társaságok, továbbá az egyéni vállalkozások 1.000 före jutó száma is meghaladja a Győr nélkül számított megyei átlagot, amely alapvetöen e térség erős gazdasági aktivitására utal. Úgy tünik, a betéti társasági forma nagyvárosi jelenség, mivel a megyei átlag Győr nélkül 5,18/1.000 lakos, a Györrel együtt számolt átlag 7,63/1.000 lakos. Az utóbbi érték magasabb a Nyugati Kapu értékénél, bár közel van hozzá. Az egyéni vállalkozók száma is a megyei átlag körül mozog, első esetben megyei átlagnál magasabb, második esetben alacsonyabb annál (3. ábra).

A nagy változások korszaka még nem zárult le, különösen egyes ágazatok például a mezógazdaság - nem mutatnak stabilitást, töretlen irányvonalat, stabil jövőképet. Éppen ezért megítélésünk meglehetösen sok bizonytalanságot hordoz, de úgy véljük, hogyha a térség iparának meghatározó ága az élelmiszeripar, akkor a mezőgazdaságnak, mint alapanyag termelö ágazatnak van jövője a térségben azért is, mert itt található a több mint egy évszázadra visszamenö tapasztalattal bíró agrár felsőoktatási és kutatási központ, Mosonmagyaróvár is.

A térség gazdasági szerkezete már tükrözi a földrajzi fekvéséböl adódó arculatot, hiszen a kereskedelem, illetve a szálláshely- és vendéglátás szolgáltatás markánsan jelen van a térségben, nemcsak a térség városára, hanem kisebb településeire is jellemzö (Levél, Hegyeshalom, Rajka). Az idegenforgalom jelentős szerepe nem a tipikus turisztikailag frekventált sajátosságokból származik, hanem a határátkeló funkcióból adódik. A megyén belüli jelentősége éppen a megyei átlagokhoz viszonyított értékekből tünik ki. A vendéglátással kapcsolatos szolgáltatások valamennyi fajlagos értéke a megyei átlag fölött van, különösen magas, mintegy kétszeres a térségben a vendéglátóhelyek száma a megyei átlaghoz képest.

A tranzitturizmus szerepét a térségben jól szemlélteti az, hogy míg a kereskedelmi szállásférőhelyek fajlagos értéke és az 1000 före jutó vendégek száma is a megyei átlag fölött van, addig a tartózkodási idő a megyei átlag alatti. Ez az összefuiggés is felhívja a figyelmet arra, hogy a későbbiekben törekedni kell a turisztikai vonzerö növelésére, két-három napos turisztikai csomagok összeállitására. A turisztikai létesítmények meglehetősen koncentráltan (az M1-es út menti településekben) helyezkednek el. A fö feladat nem is a térség megismertetése - hiszen a vendégek számából következik a térség ismertsége -, hanem a turizmus tranzit-jellegének oldása, amelynek egyik módja a tartózkodási idő növelése a természeti adottságok kihasználásával.

A gazdaság egészére igaz, hogy a pozitiv folyamatok eredményei láthatóvá váltak a térségben. A térséget nem sújtja a munkanélküliség, a tercierizálódás folyamata nemcsak a térség városát, hanem több települést is érinti. A kiépült infrastruktúra és az autópálya, az adaptív képességgel rendelkező képzett és nyelvet ismerö szakembergárda stabil kis- és középvállalkozások létrejöttéhez járult hozzá. A minden településen megjelenö vegyes vagy teljes mértékben külföldi tulajdonú termelöüzemek biztos megélhetést nyújtanak a lakosságnak, s e jól müködö, piacképes üzemek helyi adók formájában az önkormányzatok anyagi helyzetét is stabilizálni tudják (Mosonszolnok), de sok esetben szponzorként segítik a helyi civil szerveződéseket, oktatási intézményeket. 


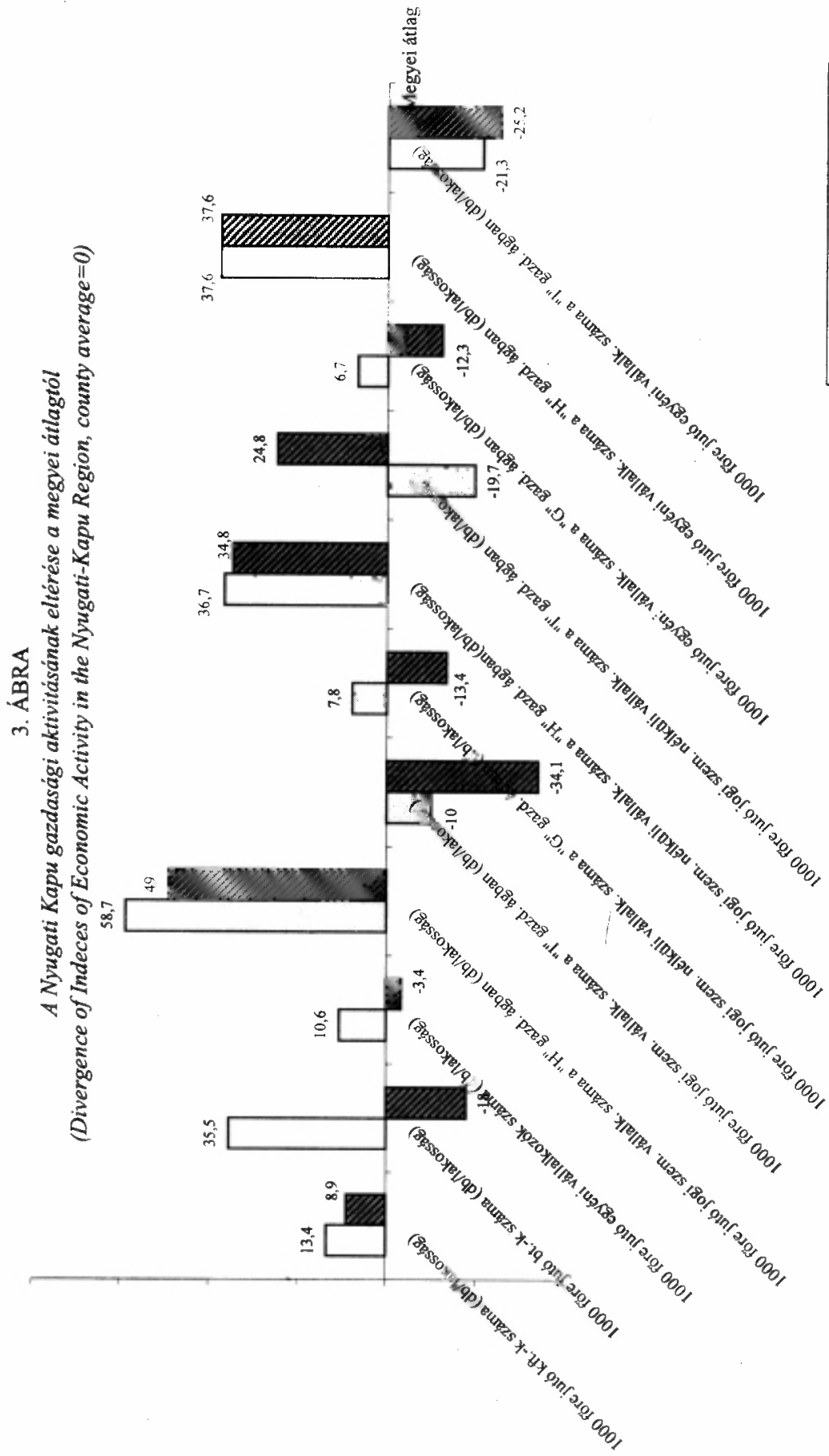




\section{Az infrastruktúra kiépitettsége}

Ami a térség infrastrukturális ellátottságát illeti, nem vonhatunk párhuzamot a vonalas infrastruktúra kiépítettsége és a pozitív gazdasági folyamatok között. Összegezve megállapithatjuk, hogy a térséget a nagy lakásépítési kedv és a hálózati infrastruktúra-épités - különösen, ami a csatornahálózatot illeti - jellemzi. A lakásépítési kedv nem egyenesen arányos a nagy alapterületủ lakások építésével, amit az is mutat, hogy az egy lakásra jutó alapterület nagysága a megyei átlag alatt marad. A vonalas infrastruktúrán belül a gázhálózat építésének kezdetén áll a térség, jelenleg a szervezés folyik. Ugyanakkor sem a személygépkocsi állomány, sem a telefonellátottság nem utal arra, hogy prosperáló térségröl van szó, erre utal a mutatók megyei átlagtól való eltérése is. (4. ábra)

\section{A kistérség földrajzi fekvése}

A Nyugati Kapu térsége határmenti térség, de még ebben a tekintetben is különbözik az ország más, hasonló helyzetü területeitől. Az eltérések az alábbiakban ragadhatók meg:

- A térséghez tartozik az ország mindig is legfontosabb, Nyugat-Európa felé tekintó határátkelőhelye, Hegyeshalom.

- Itt hármas-határ szakasz található, amely mindkét szomszédos ország felé élénk forgalmú határátkelóvel rendelkezik (Hegyeshalom, Rajka) és mindkét határátkelönél vasúti fơvonal, fơközlekedési út metszi a nemzeti határokat.

- Magyarországnak az 1990-es évek Közép-Kelet-Európában lejátszódó politikai folyamatok következtében jelenleg hét hármas-határ szakasza van, de közülük legfontosabb, legnagyobb forgalmat lebonyolító a vizsgált térség, a Nyugati-Kapu. Ez következik a határátkelök forgalmából, s következik a földrajzi helyzetéböl is. Ilyen tulajdonságokkal rendelkezö hármas-határ szakasza Magyarországnak ilyen rövid távolságon nincs még egy, hiszen a magyar-osztrák-szlovén határnál csak közúti, de nem országos jelentőségủ átkelő van. A szlovén-horvát-magyar határnál két közúti átkelö $\mathrm{s}$ egy vasúti átkeló́ van, szlovák-ukrán-magyar határnál a záhonyi határátkelö Ukrajna felé országos, sót európai jelentőségú, de a szlovákiai oldal felé az átkelés már távolabb esik, és kisebb jelentöségủ. Az ukrán-román-magyar hármashatárnál Szatmárnémeti (Románia) felé van csak átlépés. A szerb-horvát-magyar hármashatár a politikai helyzet miatt gyakorlatilag alig ủzemel, forgalma kicsi. Adottságaiban az általunk vizsgált határszakaszhoz hasonlítható a románszerb-magyar hármashatár, de a határátkelók áteresztó-képessége és forgalma nem közelíti meg a Nyugati Kapuét, $\mathrm{s}$ a határátkelók egymáshoz viszonyított távolsága is jóval nagyobb.

- Ez az egyetlen olyan határátkelö, melyhez autópálya vezet, jelenleg Hegyeshalomhoz, de hamarosan elkészül az M15-ös szakasz is, s akkor Rajkához is, s ez az autópálya mindkét oldalon autópályához hasonló szintú és minöségủ pályához csatlakozik.

- Figyelembe kell azt is venni, hogy ez a térség Szlovákia legfejlettebb térségéhez kapcsolódik, a fóvároshoz Pozsonyhoz, mely alig $20 \mathrm{~km}$-re található. Tehát valóban mondhatjuk, hogy még egy ilyen pozitív adottságokkal rendelkező határszakasza nincs az országnak. 


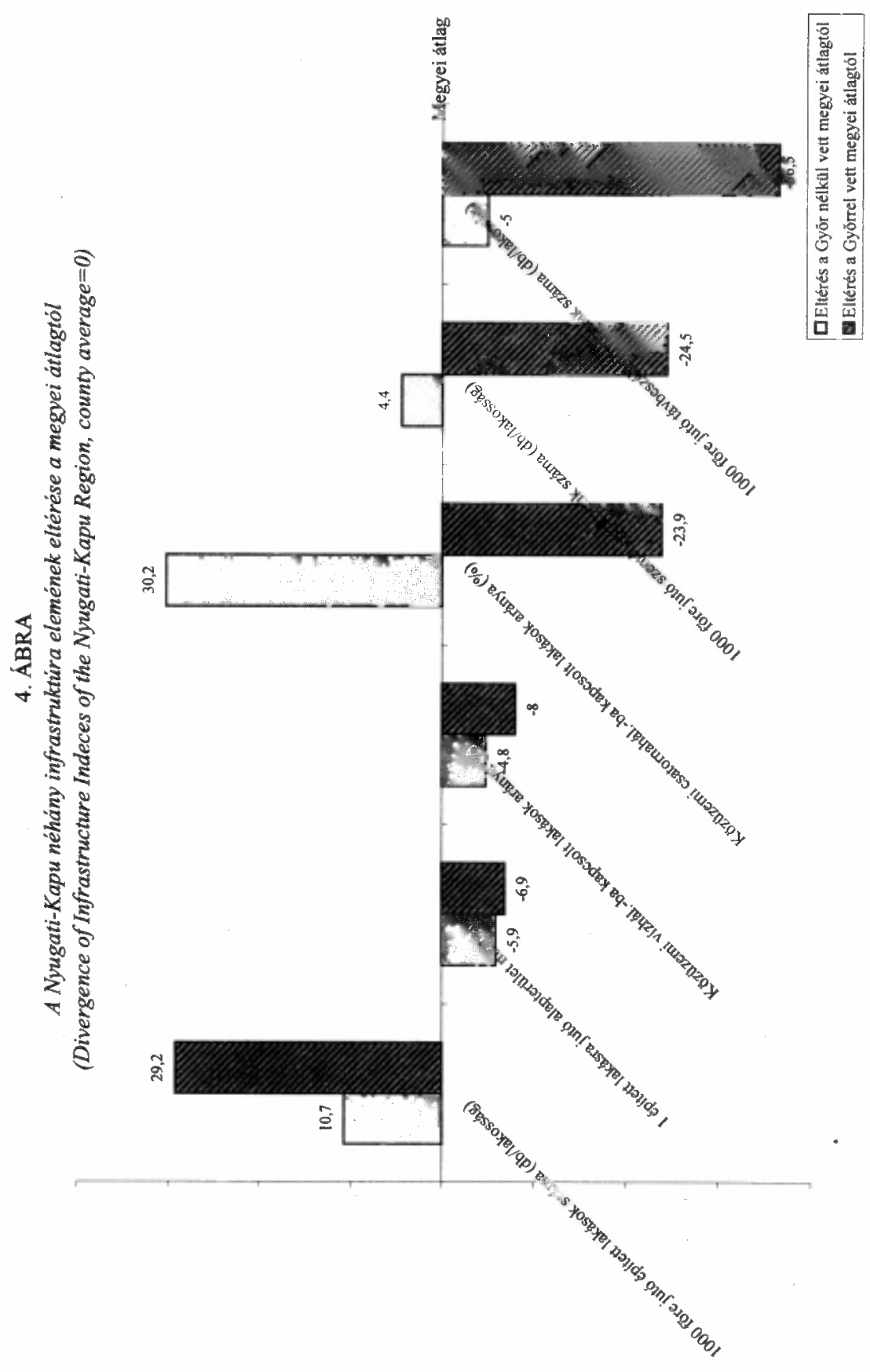

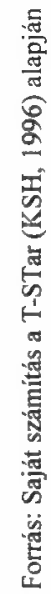




\section{A településpotenciál}

Annak a kérdésnek a megválaszolására, miszerint mennyire homogén a térség, a településpotenciál módszere szolgál. Ehhez településsoros mutatószámokat készítettem, s a vizsgált településkör valamennyi elemére egy sokváltozós, összesen 16 mutatóra épủlő rangsort állítottam fel. Közullük három változó a demográfiai viszonyokról ad tájékoztatást (öregségi index, a vándorlási mérleg, és a munkanélkưl iségi ráta). Négy változó a gazdasági aktivitást jellemzi, mint az egyéni vállalkozói aktivitás, a társas vállalkozói aktivitás, és elkészítettem a településenkénti fajlagos értéket a " $H$ ", azaz a szolgáltatás és a vendéglátást érintő gazdasági ágra és az "I" szektorra is, mely a szállítást, raktározást posta és távközlési ágazatot foglalja magában. A harmadik csoportba a turizmusra jellemzó fajlagos mutatók foglalnak helyet, a negyedik csoportot az infrastruktúra mutatói alkotják.

$\mathrm{Az}$ így kialakított mutatókat a Nyugati Kapu átlagához viszonyítottam, öt kategóriát állítottam fel. Minden egyes mutató értékét attól függően helyeztük el egy ötős skálán, hogy a viszonyított átlag körül, foolötte, vagy messze fỏlötte, alatta, vagy messze alatta van-e. Így minden egyes telepủlést 16, 1-tól 5-ig terjedó számérték jellemez. Feladatként e 12x16-os mátrix értékeit úgy kell sorba rendezni, hogy a sorrendet a homogenitás határozza meg. A rangsort a telepủlésátlaghoz hozzáadott telepuilésátlagtól mért átlagos eltérés adta, ahol a homogenitástól való eltérést bủntetó skalárral szoroztuk (büntető súly: 0,4). Az így előállított telepủléssor a 16 változó alapján megállapított sorrendet tủkrözi (5. ábra).

A települések így kapott sorrendje sok meglepetéssel nem szolgál. Nem meglepó, hogy a 12 telepủlés közuil a térség városa, Mosonmagyaróvár kerủlt az elsó helyre. A további sorrend már rejt némi meglepetést, elsősorban azt, hogy az nem mutat szoros korrelációt a népességgel. A második helyezett Levél elsósorban az idegenforgalomban betơltơtt szerepének kőszőnheti helyezését, az osztályozás szempontjából többször megelózi Mosonmagyaróvárt is ezekben a mutatókban.

A középmezőnyt hét telepủlés alkotja, melyeknél a demográfiai jellemzók és a vállalkozási aktivitás meglehetősen homogén képet mutat. A lista alján Mosonszolnok, Újrónafớ és Várbalog foglalnak helyet, közuilüuk Mosonszolnok turisztikailag nem frekventált telepủlés, így a sorrendiség kialakításában a turizmusra vonatkozó értékek miatt került a "sereghajtó"-k közé.

A sorrendben az utolsó két helyet Újirónafó és Várbalog telepủlések foglalják el. Meg kell jegyezni, hogy az értékek szórása a 16 telepủlés közül Ưjrónafó esetében a legnagyobb (33), ami jelzi a telepúlés helyzetének ellenmondásosságát. Bizonyos mutatókban, mint például a vándorlási egyenleg, a legelókelőbb helyezést éri el, s így érthető, hogy az épített lakásszám is magas, ami a bevándorlók lakásépítési kedvére utal. Ugyanakkor a vállalkozói aktivitás és a kereskedelmi szállásférőhelyek tekintetében az utolsó kategóriába tartozik. Az utóbbi hiányzik a faluban, ebben elörelépés akkor várható, ha a kastélyt, mely a kỏzelmúltig kórházként üzemelt, át tudják alakítani szállásférőhellyé. A telepủléskőrben Várbalog utolsó helyezése nem okoz meglepetést, az aprófalu szinte minden mutatójában a térségi átlag alatt maradt, talán a személygépkocsik magas száma figyelmeztet a közlekedési árnyékhelyzetére. Jelenlegi helyzetén sokat javíthatna az Albertkázmérpusztán nyitható kerékpáros határátkelóhely, s ezzel megnyílhatna a turisták számára. 
Egy kistérség sikerének titka - avagy tettek és tervek a Nyugati-Kapu Térségfejlesztési Társulás „házatáján” Tér és Társadalom, 11. 1997. 4. 25-43. p.

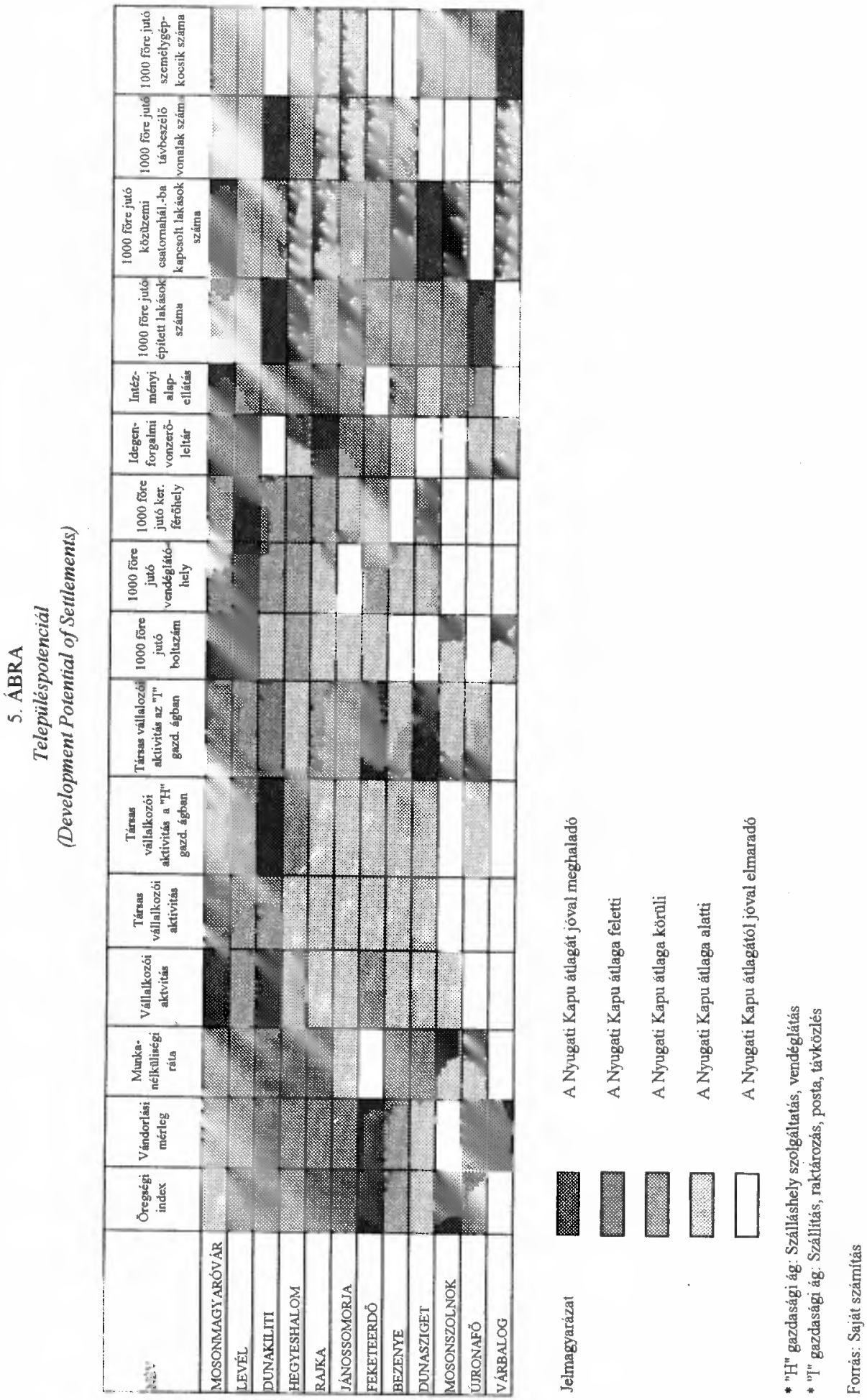


A sorrend és a sorrendiséghez tartozó szórás-értékek egy kvázi homogén térség jegyeire utalnak. Ugyanis abból, hogy a rangsorban a térség városa nem különül el arra következtethetünk, hogy hasonló fejlettségü, csak kisebb népességszámú települések veszik körül. Ez alól csak a rangsor alján elhelyezkedỏ két település kivétel (Újrónafó és Várbalog), melyek a lemaradás relatív jegyeit hordozzák.

A térség a tipikus vidéki térségektől abban különbözik, hogy itt a város és térségének településpotenciálja nem válik ketté, van a térségben a városon kívül három-négy olyan telepưlés, amelyik fajlagos mutatóiban a városhoz hasonló jegyeket hordoz, mint például Levél, Dunakiliti, Rajka, Jánossomorja. A 12 település közül mindössze két település van, amelyek a relatív lemaradás jegyeit hordozzák, Újrónafó és Várbalog, de közülük is Várbalog az egyértelmüen leszakadó. Ezek a vizsgálatok arra engednek következtetni, hogy a Mosonmagyaróvár és Várbalog elhagyása esetén szinte homogén a térség.

\section{A fejlödést gyorsitó tényezök}

A fejlödést soha nem egy tényezö váltja ki, hanem vannak tényezők melyek erösítik, vannak melyek gyengitik a annak folyamatát, s ezek egymásra hatva mindkét irányban érződnek. Ebben a térségben a fejlődést erősítö, sőt a fejlödésben egymást erösitő tényezők figyelhetők meg.

Az egyik ilyen ösztönzö tényezö a határmenti fekvés, az osztrák határmentiség, a nálunk jóval fejlettebb térséghez való kapcsolódás. Már az 1980-as évek közepétöl, amikor a gazdaság liberalizációja elindult, majd később a határ is egyre nyitottabbá vált, elindult először lakossági szinten, majd a gazdasági szereplök között is a kapcsolatkeresés, az együttmüködés. Ezt erösítették azok a rokoni kapcsolatok, melyek szálai a második világháborúhoz és az 1956-os forradalomhoz vezetnek vissza. A német nemzetiségủ Mosonszolnok, Jánossomorja, Levél, de még Rajka és Dunakiliti esetében is a települések lakossága élénkítette kapcsolatait a második világháború után kitelepített falubeliekkel, rokonokkal, melyek először a személyes kapcsolatok erösítésében kerültek felszínre, majd a gazdaságban vegyes vállalatok, vagy teljes német, vagy osztrák tulajdonú cégek formájában. Ezt a folyamatot segítette a német nyelv ismerete, mely ezekben a telepulésekben sokak számára az anyanyelvet jelenti. A német nyelv tudása a határon túli munkavállalást is lehetővé tette, és legálisan vagy illegálisan, de már az 1980 -as évek végén megindult a munkavállalók serege a határon túlra, közülük legtöbben mezögazdasági idénymunkát vállaltak, de jelentős számú volt a mesteremberek munkavállalása is.

A külföldi munkavállalásnak kettős hatása volt, részben megoldotta az 1990-es évek elején jelentkező munkanélküliségi problémát, illetve gazdasági kapcsolatok építését indukálta. Így a gazdasági tapasztalatok és a gazdasági társaságok inditásához szükséges tỏke és kapcsolatrendszer egyszerre volt jelen. Ezért jellemzö a térségben a nem nagy tőkével, de stabilan müködỏ kis- és középvállalkozások köre, a kevés osztrák tőkével megalapitott vegyes vállalatok magas száma. Röviden úgy fogalmazhatjuk, hogy magas a térség lakosságának adaptációs képessége.

A kapu-szerepből, a határátkelö funkcióból adódik a tranzitforgalom nagysága. Ezt a forgalmat felismerve kereskedelmi szállásférỏhelyek kialakításával (amelyek fajlagos értéke meghaladja a megye bármely térségének átlagát), éttermek, kereskedelmi egységek nyitásával sikerült a térségben megállítani. E funkciók 
erősítésével elindult a térségben a tercierizálódảs folyamata, a munkaerỏ - beleértve a nöi munkaeröt is - lekötése a szektorban. Tehát a térségben a foglalkoztatás valódi átstrukturálódása indult el. Ez a folyamat fơleg az autópályát és az M15-ös utat érintő településekben figyelhető meg, sajnos az erömü okozta környezeti gondok, majd politikai viharok, a Hágai Nemzetközi Bíróság döntésére való várakozás visszafogta a turizmus fejlödésének pozitiv folyamatait a társulás által érintett szigetközi telepulésekben. A települési önkormányzatok döntéshozói és a potenciális vállalkozók várakozó álláspontra helyezkedtek, visszafogták a természetes növekedés ütemét. Ma ezekben a falvakban (Feketeerdö, Dunasziget) megjelentek a kúlföldiek, az osztrákok, de nem mint turisták, hanem elsősorban mint ingatlanvásárlók.

A pozitív folyamatok eredményei láthatóvá váltak a térségben. A térséget nem sújtja a munkanélkuliség, a tercierizálódás folyamata nemcsak a térség városát, hanem több telepưlést is érinti. A kiépült infrastruktúra és az autópálya, adaptív képességgel rendelkezö képzett és nyelvet ismerö szakembergárda stabil kis és középvállalkozások létrejöttéhez járult hozzá. A minden településen megjelenö vegyes vagy teljes mértékben külfóldi tulajdonú termelöüzemek megélhetést biztosítanak a lakosságnak, $\mathrm{s}$ helyi adók formájában az önkormányzatok helyzetét is stabilizálják.

\section{Nyugati-Kapu-sikerrégió}

Az utolsó kérdésre kell még válaszolnunk, azaz "sikerrégió"-nak nevezhetö-e a térség? Ehhez elsősorban azt kell tudnunk, hogy ez a fogalom valójában mit is takar. Úgy véljük, a sikeres régió mást jelent keleten és mást nyugaton. Mindig egy nagyobb gazdasági egységbe kell belehelyezni a vizsgált térséget ahhoz, hogy el tudjuk dönteni sikerességét, azaz a kérdés az, hogy a meglévö adottságait mennyire volt képes kihasználni, lehetöségeivel mennyire tudott élni. Ez a képlet többszereplös, részesei a lakosság, az önkormányzat, a gazdasági és civil szervezetek stb.

Ez a térség fóldrajzi helyzetét tekintve kedvezményezett. De nem beszélhetnénk sikerekről, ha ezzel az adottsággal nem tudott volna élni, a sikerhez tehát a helyi társadalom adaptív tagjai és a döntéshozói jelentősen hozzájárultak. A háború után elzárt térség a nyitásra tudatosan készullt, és a határmentiség előnyét kihasználva a kủlsỏ kapcsolatokra alapozta gazdaságát, beleillesztve ebbe a tranzitfogalom kínálta turizmus-fejlesztést is. Ma a Nyugati-Kapu térségében lejátszódó folyamatokat sikeresnek tekinthetjük, a térség a rendszerváltás után sikerrégióvá vált, de ennek megörzése csak az előremenekülés stratégiájával. a mindennapok kemény munkája árán lehetséges.

A sikeresség nem jelenti a tökéletességet, itt is megtaláljuk a térséget jellemzö gyengeségeket, a leselkedö veszélyeket, de mint azt a térség SWOT-analizise is mutatja, több az erősség, és a lehetőség a térségben, mint a negatív folyamatokra utaló jel. 


\section{A térség SWOT-analizise}

- földrajzi fekvés

- jó infrastruktúra

- autópálya

- hármashatár

- európai közlekedési folyosók metszéspontja

- $\quad$ kedvező gazdasági szerkezet

- alacsony munkanélküliség

- külföldi tőke a gazdasági egységekben

- erdógazdálkodás súlya magas

- kedvezö demográfiai állapot

- relatív fejlett térség

- természetvédelmi területek (Szigetköz, Hanság)

- hatalmas tranzitforgalom

- nagy szálláshelykínálat

- $\quad$ sok vendég, magas a külföldiek aránya

- a térség városa tagja lett a szövetségnek Lehetôségek

- Bécs-Pozsony-Györ eurorégió

- hármashatármenti együttmüködés

- termálvíz

- határátkelési funkció erósítése

- raktározási funkció erósítése

- raktárbázis kialakítása

- logisztikai központ kiépítése

- $\quad$ szállítmányozás ágazatban súlyának növelése

- a Fertőmenti és Dunamenti kerékpárút összekapcsolása

- be- és kiáramló utazók pár napos tartózkodássá való lekötése

- üdülóterületek kialakítása Szigetközben

- üdülési programcsomagok kidolgozása

- vendégváró szakemberek képzése különbőzỏ szinten és formában

- $\quad$ szolgáltatási szektor fejlesztése

- különböző nemzetiségek kultúrájának egymás között élése

- civil szervezetek erõsítése

- határon túli munkavégzés

- teljes telepúlési infrastruktúra kiépülóben

- kamarák gazdaságszervező funkciója

- térségfejlesztési iroda működtetése

- a térség városában kihasználni az egyetem bázisán elindítható innovációs centrumot

\section{Gyengeségek}

- Szigetköz problematikája

- környezeti szabályozás

- rekultiválatlan kavicsbánya területek

- rekultiválatlan ipartelepek

- $\quad$ szennyezés-érzékeny talaj

- településközi utak hiánya

- $\quad$ szerény idegenforgalmi vonzerő

- belvízveszély

- kevés vendégéjszaka

- térségi turizmus marketing hiánya

- kevés és rendszertelen programajánlat

\section{Veszélyek}

- határmentiség - romló közbiztonság

- veszélyeztetett ifjúság

- munkaerö hiány

- óriási tranzitforgalom - bünözés növekedése - veszélyeztetett réteg a fiatalság

- turisztikai programajánlat szegényes

- Bős-Nagymaros ügyben elhúzódó állásfoglalás, bírósági per 
A térséganalízis eredményeire támaszkodva és a SWOT analízis meghatározását követóen a térségre vonatkozó fejlesztési koncepció legfontosabb alapelveit kerülttek meghatározásra, majd ennek segítségével a prioritásokat, s azok programjai fogalmazódtak meg a helyi döntéshozók, és a térségfejlesztésben érdekelt minden más szereplók segítségével.

\section{A térségfejlesztési koncepció alapelvei}

A koncepció elkészítésének alapja kettős, egyik oldalról az 1996-ban elfogadott Györ-Moson-Sopron Megyei Területfejlesztési Koncepció megszabja a térség fejlesztésének legfontosabb csomópontjait, a megyefejlesztésben elfoglalt helyét, amely helyi program készítése során követendő. A koncepció készítésének másik oldala a mikrovizsgálatok alapján elkészült térséganalizis, amelynek eredményéből, a szintézisből a konkrét stratégiai irányok és a térségfejlesztéshez szükséges programok megfogalmazása következik.

A legfontosabb igazodási pontok:

- A térség a kvázi fejlett Györ-Moson-Sopron megyén belïl is nagyobbrészt az a gazdasági innováció pólusterületéhez tartozik;

- A nyugati határmentiség önmagában hordozza a gazdaság átstrukturálódásának felgyorsulását;

- Közlekedési ellátottsága, s ebból fakadó szerepe egyedülálló az országban;

- A Bécs-Pozsony-Györ formálódó eurorégió része.

Az igazodási pontokból már következik:

- nem elmaradott térség;

- nem depressziós térség;

- nem rurális jegyeket hordozó térség.

\section{Hanem:}

- $\quad$ kedvezỏ népességstruktúrájú;

- kedvező humán tőkével rendelkező;

- kedvezó gazdasági szerkezetú és aktivitású;

- a munkanélkuliség nagyon alacsony;

- a tercierizálódás folyamata a térség falvait is érinti.

\section{Sikerének titka:}

szubjektív tényezők:

- innovációra képes lakosság

- a helyi döntéshozók adaptív képessége, széles-látókörüsége

- az önkormányzati döntéshozók együttmüködési készsége

- a beáramló tóke fogadóképességének megteremtése

objektív tényezö:

- földrajzi fekvés 
A térség fejlődése számára szerencsésnek nevezhetö tényezök csak akkor válnak valóban hatásossá, akkor erösítik a folyamatokat pozitív irányba, ha tudatos, összehangolt stratégiaépités folyik. Ez a stratégiaépítés már a 90-es évek elején elkezdödött, részben azzal, amikor a településszövetség gondolata érlelödött, s elindult egy alulról építkezés folyamata, részben azzal, hogy a megye a magyar megyék közül nagyon sokat megelőzve, elsők között kezdte el a megye számára a fejlesztési koncepció előkészítését, majd elkészíttetését. E két irányból elindult folyamat erősítette egymást, s korán elvezetett a tudatos térségfejlesztéshez.

\section{A térségfejlesztés folyamata és fö pillérei}

A térségfejlesztés egy folyamat, és soha nincs "elég fejlett" térség. Ha ez a folyamat megtorpan vagy megáll, az magában hordozza a visszalépést. Csak egy út lehetséges, az előremenekülés. Tehát ebben a fejlett, illetve a kvázi-fejlett térségben a fejlődés folyamata csak akkor lesz torretlen, ha stratégiai irányokhoz igazodva akciótervet valósítanak meg, ha van mihez igazodniuk, ha van mit megvalósítaniuk. Mindehhez alapvetöen három alapvető fontosságú elemre van szükség:

\section{A három pillér:}

- meghatározott prioritások és az abból kơvetkezö programok;

- a térségfejlesztés szereplöi, akik/amelyek lehetnek személyek, betöltött funkciók és intézmények;

- források.

$\mathrm{Az}$ eredményes területfejlesztés kistérségi szinten is csak akkor müködik, ha mindhárom szegmens jelen van és részt is vesz a folyamatban.

\section{A térséganalizisböl következő prioritások és programjai}

A prioritások, főbb fejlesztési irányok csak akkor térségspecifikusak, ha a térséganalízis megállapitásain alapulnak. De minden hazai kistérség fejlesztési prioritásait két célirányzat alá kell rendelni, a térséganalízis eredményeitöl függetlenül. Ez a két célirányzat:

- A humán eröforrások fejlesztése;

- Környezetbarát gazdaságfejlesztés a fenntartható fejlődés elvei alapján.

A Nyugati-Kapu Térségfejlesztési Társulás számára hat prioritás meghatározására került sor (a prioritások sorszáma nem jelenti a fontosságuk sorrendjét). Az egyes prioritások több programot és alprogramot tartalmaznak.

A Nyugati-Kapu Térségfejlesztési Prioritásai:

A. prioritás: Közösség-építés.

B. prioritás: Tercierizálódás folyamatának erösitése, a turizmus fejlesztése.

C. prioritás: A térség $\mathrm{K}+\mathrm{F}$ tevékenységének összekapcsolása a mezögazdasági és élelmiszeripari tevékenységgel.

D. prioritás: Tájkép és tájérték, a környezet védelme.

E. prioritás: Az infrastruktúra és közlekedési hálózat fejlesztése. 


\section{A. prioritás: a közösségépités prioritáshoz rendelt programok:}

A térségfejlesztés alapvető célja az adott területen élő népesség életminőségének javítása. Külsö beavatkozással elérhető a gazdaság egyes ágazatainak fejlesztése, ezzel például a munkanélküliség csökkentése, a helyi jövedelmek emelése. Ha a fejlesztés idegen testként épül be, akkor az idegen testet a "szervezet" könnyen kidobhatja, vagy maga az idegen test választja ezt az utat. Ez csak arra utal, hogy egy külső fejlesztés csak akkor szolgálja a fejlődést, ha az ott élök el tudják fogadni, sőt fontossága a közösség részéröl fogalmazódik meg.

A fejlesztési programokat meg kell ismertetni a helyi lakossággal, annak különbözö rétegeivel ahhoz, hogy elöször csak felkeltse a figyelmüket, majd véleményükkel a folyamatokat befolyảsolni is tudják. Eredményes programokhoz nem elég a forrás megszerzése, a program elfogadtatása is szükséges, ezért a közösség-építésnek hatása van a jövőkép formálására, amely az egész térséget érinti.

A közösség-építés sokszereplös folyamat, melynek szintjei a következők:

- Lakossági;

- Helyi döntéshozói szint;

- Gazdasági szereplők;

- Helyi katalizátorok (pedagógusok, civil szervezetek aktív tagjai;

- Térségi prominencia.

A folyamat lépései:

1. A térségfejlesztési koncepció megismertetése különböző rétegekkel;

2. A civil szervezetek bevonása a térségfejlesztés folyamatába, a programok ismertetésébe;

3. Image építés;

4. Monitoring rendszer a térségfejlesztési feladatokra;

5. A helyi társadalom épitése;

5.1. alprogram: veszélyeztetett (alkohol, drog) rétegek (ifjúság) kezelése;

5.2. alprogram: munkanélküli réteg képzése, átképzése;

5.3. alprogram: ifjúsági programok (pl. sportrendezvények, kulturális rendezvények);

5.4. alprogram: civil szervezetek létrehozása, erösítése (pl. nyugdíjasok egylete, vendégvárók egyesülete, $\mathrm{stb}$.)

6. Az eurorégió épitése - euro-mikrorégió építése.

B. prioritás: A tercializálódás folyamatának erốsitése, a turizmus fejlesztése prioritás programjai

A térséganalízis eredményei azt mutatták, hogy a gazdaság szerkezetében túlsúlyban van a tercier szektor aránya, a meglévő vállalkozások többsége ebben a szektort képviseli, a térségben a kereskedelemnek, a vendéglátásnak és az átmenő turizmusnak meghatározó szerepe van. Ezt a funkciót kell tovább erősíteni, mely csak összehangolt programokkal képzelhető el. 
1. Komplex turisztikai program készítése.

2. Vendégváró szakemberek képzése.

3.A turisztikai kínálat növelése, a programkínálat lebontása és összehangolása a három mikrotérre vonatkozóan

3.1. Hanság mikrotér szálláskínálat bővítése, a mikrotér bekapcsolása a turizmus áramlatba.

3.2. Korridor települései: a turisták tartózkodási idejének növelése.

3.3. Szigetköz települései: üdülöterületek kialakítása, szolgáltatási szektor bővítése.

4. Szállítmányozási és raktározási funkció bỏvítése.

C. prioritás: A térség $K+F$ tevékenységének összekapcsolása a mezõgazdasági és élelmiszeripari tevékenységgel

Óriási elönye a térségnek a Mosonmagyaróváron müködő egyetem. Jelenleg ennek hatása az egész térségben nem érezhető. A rendszerváltás után a mezőgazdasági ágazat válsághelyzete kihatott a mezőgazdasági felsőoktatásra is, megjelentek a túlképzés tünetei, de egyúttal szükség volt a megváltozott piaci és termelési körülményekhez alkalmazkodó szakemberek képzésére, a korábban végzett szakemberek átképzésére. Az agrár-felsőoktatás túlélte a válságos éveket, a képzés iránti igény ma is fennáll. A térség részben az egyetemi oktatók száma miatt, részben a térségben lévö agrár felsőoktatás hatása miatt, és a korábban nagy területeket lefedő tangazdaságok müködéséhez szükséges szakember gárda miatt is nagyon gazdag agrár szakemberekben. Ezt a szellemi tökét kamatoztatni kell, s a térség mezögazdaságában a szellemi tökére alapozott minöségi agráriumot kell elötérbe helyezni. A kutatóbázis és a termelők közötti kapcsolatot a lehető legszorosabbra kell szőni. Ki kell választani azokat a profilokat, melyekben ez a kapcsolat kiépíthető, $\mathrm{s}$ így egy $\mathrm{K}+\mathrm{F}$ tevékenységgel átszőtt agrárágazat jelenhet meg a térségben.

1. Az agrárprogram kidolgozása;

2. Együttmüködésen alapuló kapcsolatépítési program a helyi mezőgazdasági

termelők és az egyetem között;

3. Dán típusú szövetkezetek szervezése;

4. Az agrárkamara és a gazdák közötti kapcsolat mélyítése;

5. A termelés és az értékesítés konfliktusának oldása.

D. prioritás: A tájkép és tájérték, a környezet védelme prioritás programjai

A térség szigetközi településeire és a korridor mikrotérre a Szigetköz Rehabilitációs és Térségfejlesztési Terve, a Hanság mikrotérre a Fertó-Hanság Térség Regionális és Tájrendezési Terve részletes feltárást végzett a táji értékekre vonatkozóan és részletesen megfogalmazta a legfontosabb akciókat azok, s a környezet védelmére. Ezek ismeretében fogalmaztuk meg ennek a prioritásnak a programjait. 
1. Faluszépítỏ és egységes kép kialakitó program - térségi szintü szervezés;

2. Vízbázis-védelem program;

3. Bányatavak rekultivációs program;

4. Vörösiszap- kezelés és ártalmatlanitás program;

5. Zöldfolyosó program;

6. Krisztina-berek lágyturizmus programja;

7. Az épített környezet védelme program: sváb házak rehabilitációs terv.

E. prioritás: Az infrastruktúra és a közlekedési hálózat fejlesztése

A "D" és az "E" prioritás sok esetben összekapcsolódik, hiszen akár a hulladék elhelyezés, akár a szennyvíz-csatornázási program legalább annyira a környezetvédelemhez is tartozik, mint amennyire a infrastruktúrához sorolható, hiszen ezen infrastruktúra épités szolgálja a környezetvédelmet.

1. A gázprogram befejezése, településenkénti fogyasztói rákötések - településen belüli úthálózat helyreállítása;

2. A szelektív hulladékgyűjtés megszervezése, a lakosság felkészítése;

3. Hulladékudvarok kialakítása;

4. Kerékpáros útvonalak kijelölése, kitáblázása (K4: Dunakiliti-Mosonmagyaróvár-Krisztina berek);

5. Telepullésközi utak épitési programja, ütemezése;

5.1. Várbalog-Mosonszolnok/Irénmajor-Hegyeshalom útszakasz megépítése;

5.2. Jánossomorja-Újrónafó útszakasz megépitése;

5.3. A Jánossomorja-Acsalag útszakasz kiépitése (kapcsolódás Tókőzhőz).

\section{További lépések a siker felé}

A térségfejlesztés folyamata meghiúsulhat, ha a prioritások és programjaik nem jutnak túl a megfogalmazáson, a megvalósitásukhoz nem gondoskodunk az egyes folyamatokban résztvevő szereplökről és ha nem vesszük számba a megvalósításhoz szứkséges pénzügyi eszközök forrástérképeit. A térségre vonatkozó területfejlesztési koncepció ezeket is tartalmazza. Ennek elkészülte után a területfejlesztés sikerének titka a prioritásokhoz tartozó programok megvalósitása a részletes projektekre történö bontással. Ez lassú folyamat, melynek eredménye csak hosszabb távon mérhető le, s csak akkor lesz eredményes, ha lehetőségekkel mind a lakosság, mind az önkormányzat döntéshozói, mind a gazdasági szervezetek élni trudnak, és élni akarnak. Az eddigi partnerségi viszony, az adaptációra képes helyi szereplök és a térség társadalmának, gazdaságának nyitottsága döntően hozzájárult a térség eddigi sikeréhez, de megtartásához nélkưlözhetetlenek a további eröfeszítések, melyekre szépszámmal találunk példákat.

A koncepció elfogadása óta a korábbinál is céltudatosabban folyik a térségfejlesztés. A prioritások programjainak megfelelöen még ebben az évben elkészül a turizmus és az agrárium fejlesztési programja, a szervezési előkészületek után a közeljövőben alakul meg a Nyugati-Kapu, illetve a szomszédos osztrák és szlovák kistérségek egyuuttmúködésén alapuló ,mini eurorégió", mely a nyitottságával, lehetỏségeivel az újszerüség és a további siker záloga lehet. 


\section{Irodalom}

A térségfejlesztés tórsadalmi és gazdasági feltételei a Nyugat-Kapu településeiben I. (1997) Kozlemények 54. (Témavezető: Szörényiné Kukorelli Irén) MTA RKK Nyugat-Magyarországi Tudományos Intézet, Györ, 135 o.

A térségfejlesztés társadalmi és gazdasági feltételei a Nyugat-Kapu településeiben II. (1997) Közlemények 65. (Témavezetô: Szörényiné Kukorelli Irén) MTA RKK Nyugat-Magyarországi Tudományos Intézet, Györ, 45 o.

G. Fekete É. (1997) A kistérségi tervezés néhány sajátossága. Tér és Társadalom 3. sz. 101-106. o.

Guo, R. (1996) Border Regional Economics. Physica Verlag Schpringer Verlag Co. 1996. Heidelberg 1850 .

Györ-Moson Sopron megye teruletfejlesztési koncepciója (Témavezetö: Rechnitzer János) V. köt. Koncepció. MTA RKK Nyugat-Magyarországi Tudományos Intézet, Györ, 1996

Kovács Géza (1997) Tapasztalatok és megfontolások a fejlesztési koncepciók továbbfejlesztéséhez Tér és Társadalom 3. sz. 107-112. o.

Szorényiné Kukorelli Irén (1995) A határon átnyúló kapcsolatok Györ-Moson-Sopron megye határmenti telepuléseiben. Enyedi Gy. (szerk.) Bécs-Pozsony-Gyốr gazdasági háromszög együttmüködési lehetóségei ès jövöbeli perspekttvái (kutatási jelentés) MTA RKK Nyugat-Magyarországi Tudományos Intézet Közleményei 9., Györ, 20 o.

Szơrényiné Kukorelli Irén (1996) Határon átnyúló térkapcsolatok a Nyugat-Dunántúlon. Pál Á, Szónokyné Ancsin G (szerk.) Határon innen - határon túl. JATE Gazdaságfoldrajzi Tanszék - Juhász Gyula Tanárképző Főiskola Gazdaságfőldrajzi Tanszék, Szeged, 354-366. o.

\section{SECRETS OF SUCCESS OF THE „NYUGATI-KAPU” REGION: PLANS AND ACTIONS FOR DEVELOPMENT}

\section{IRÉN SZÖRÉNYI}

The study aimed at reviewing the main factors of the success of the micro-region of "Nyugati-Kapu Regional Development Association". We focused on human, geographical and environmental conditions of development. Geographical situation determined by the vicinity of the national border and transportation routes of international importance are a major potential for economic development. It must be exploited by the local leaders and entrepreneurs through initiation of international co-operation and extension of economic relations. In this way, favourable geographical conditions must be combined by "human factors to achieve social progress in the region. A concept for regional development that rests on the analysis of endogenous resources and geographical potential (summarised in the SWOT analysis) shall give a further stimulus for the collaboration and success of mutual programs. The study also presents the priorities and programs that based on the concept and should be realised in the region. 